Environment Conservation Journal 14(3)177-181, 2013

ISSN 0972-3099 (Print) 2278-5124 (Online)

Abstracted and Indexed

\title{
Studies on limnological characteristics and fish fauna of River Bhagirathi in Uttarkashi (Garhwal Himalaya)
}

\author{
D.R.Khanna' ${ }^{1}$, S.K.Pathak ${ }^{2}$ and Shambhu Prasad ${ }^{2} \bowtie$
}

Received: 25.07 .2013

Revised: 28.08 .2013

Accepted: 16.11.2013

\begin{abstract}
Limnological parameter and plankton diversity are an important criterion for determining the suitability of water for irrigation and drinking purpose. River Bhagirathi has greatest importance for humankind. The specific status of Physiochemical parameter and diversity of plankton in River Bhagirathi have been studied through monthly surveys in two annual cycles (20010-11 and 2011-12) and annual survey of fishes in two annual cycles (20010-11 and 2011-12). The water remained moderately alkaline (pH 7.7) while velocity $(1.23 \mathrm{~m} / \mathrm{s})$, TS $(844 \mathrm{mg} / \mathrm{l})$, chloride $(5.04 \mathrm{mg} / \mathrm{l})$, hardness $(96.73 \mathrm{mg} / \mathrm{l})$ and alkalinity $(67.11 \mathrm{mg} / \mathrm{l})$ showed low mean values. Average dissolved oxygen levels were at $8.54 \mathrm{mg} / \mathrm{l}$ while average nitrate and phosphate levels were $0.048 \mathrm{mg} / \mathrm{l}$ and $0.072 \mathrm{mg} / \mathrm{l}$ respectively.
\end{abstract}

Keywords: River Bhagirathi, Temperature, pH, Disolved Oxygen, BOD and fish fauna

\section{Introduction}

Biological production in any aquatic body gives direct correlation with its physico-chemical status which can be used as trophic status and fisheries resources potential (Jhingran et al., 1969). Water is a prime natural resource, a basic human need and a precious national asset and hence its use needs appropriate planning, development and management (Khanna, et al. 2010). Life in aquatic environment is largely governed by physicochemical characteristics and their stability. The most characteristic criterion to assess the trophic structure of a river remains to be primary productivity studies. Due to tremendous development of industry and agriculture, the water ecosystem has become perceptibly altered in several respects in recent years and as such they are exposed to all local disturbances regardless of where they occur (Khanna and Chugh, 2004). Fishes occupy all three levels such as primary, secondary, tertiary consumer of food web in aquatic ecosystem. Man being the top carnivore in this food system as it is a very good source of protein. Every year, During the Yatra season lacs of tourist come from all over the globe to visit Gangotri and Gomukh and the river has to bear lot of additional

Author's Address

${ }^{1}$ Deptt. of Zoology and Env. Sc., Gurukula Kangri University, Haridwar

${ }^{2}$ Department of Zoology, Govt. P.G. College, Mhow (M.P.)

Email: Shambhuenv@gmail.com stresses caused by a number of factors. As a result, the river has few stress free zones. So study on Limnological characteristic of river has high importance, the study of their trophic status may help in optimum utilization and conservation. Therefore, the present investigation attempt to study of Limnological parameter and their relationship, phytoplankton, zooplankton status and diversity and fishes (species) in River Bhagirathi during the study period.

\section{Materials and Methods Study Area}

The study area is located in Garhwal Himalaya which is an important zone of Middle Himalaya and a part of state Uttarakhand in India. It encompasses in the Uttarkashi district and the location of Uttarkashi on globe is on latitude $30^{\circ} 22^{\prime}$ - $31^{\circ} 25^{\prime} \mathrm{N}$ and Longitude $77051^{\prime}-99^{\circ} 27^{\prime} \mathrm{E}$ while the height from the sea level is 1180 meters. This area is very rich in biodiversity and the entire region of Himalayas is rich in terms of major fluvial systems of the Ganges, Yamuna and their tributaries. In the Garhwal Himalayas the Ganga river system is formed by two main streams, the Bhagirathi and the Alaknanda. The Bhagirathi is an important river originating from Gaumukh in Gangotri glacier (within the physical boundary of Uttarkashi district) and passes via thickly populated 


\section{Khanna et al.}

towns like Uttarkashi, Tehri and Devprayag. At Devprayag it meets the Alaknanda and from the confluence downstream it is called the Ganga, which flows down and emerges as the river of plains at Rishikesh-Haridwar. The river channel of the Bhagirathi at Uttarkashi exhibits a gradual increase in its width; the river bed possesses large boulders and pebbles etc.

\section{Sampling and Analysis \\ Physico-chemical Analysis}

The present study was conducted on River Bhagirathi covering a stretch of approximately 76 $\mathrm{km}$ from upstream (S1) at Harsil to downstream (S4) at Uttarkashi. The study was carried out for a time period of two year from October 2010September 2012 on monthly basis. Seasonal relation was later found to know the effect of different environmental conditions on river water. Water samples were collected every month early in the morning in sterilized sampling bottles and were analyzed for twenty two important physical and chemical Parameters. Few physico-chemical parameters like Temperature (0C), Velocity $(\mathrm{m} / \mathrm{s})$, $\mathrm{pH}$, Free CO2 (mg/l), and Dissolved Oxygen (mg/l) were performed on spot and other parameters like Turbidity (JTU), Total Solids (mg/l), TDS (mg/l), TSS (mg/l), Total Alkalinity (mg/l), Total Hardness (mg/l), Chloride (mg/l), BOD (mg/l), COD (mg/l), Phosphate $(\mathrm{mg} / \mathrm{l})$ and Nitrate $(\mathrm{mg} / \mathrm{l})$ were analyzed in laboratory by following the methodology of APHA (1998); Khanna and Bhutiani (2004); Trivedi, and Goel (1986); Wetzel and Likens (1991). Temperature, Velocity was measured by using Celsius thermometer (0-110 0C), and flow meter. Turbidity, Conductivity and $\mathrm{pH}$ were measured by using Jackson Turbidity unit, Conductivity meter and digital $\mathrm{pH}$ meter. Total Solids TDS, TSS were measured by volumetric analysis. Total Alkalinity, Total Hardness, Chloride, Free $\mathrm{CO}_{2}$, DO BOD and COD were analyzed by titration method. Phosphate and Nitrate were analyzed by using UV-VIS Spectrophotometer and Sodium and Potassium by Fame photometer.

\section{Fishes Analysis}

For the study of icthyofauna, Fishes were collected by jaal and scoop nets with the help of local fishermen from the selected sites. They were then transferred in prelabeled containers and preserved in $5 \%$ formalin. The fishes were identified by following the identification keys of Jhingran et al. (1989); Jayaram, (1999); Day, (1978) and Badola, (1979).

\section{Results and Discussion}

Results of Limnological study are summarized in Table- 1. Water temperature was observed to be highest during summer $2011-12 \quad\left(17.5^{\circ} \mathrm{C}\right)$ and lowest during winter $2010-2011\left(10.6^{\circ} \mathrm{C}\right)$. The overall average value of water temperature was $15.2^{\circ} \mathrm{C}$. A good synchronization between temperature and dissolved oxygen was seen. Temperature showed a significant inverse relationship with dissolved oxygen. Such an inverse relationship has also been observed. Same trend of temperature was observed by Khanna (2001) in river Ganga at Hardwar. More or less a similar status of temperatures has been reported by Badola and Singh (1981) in river Alaknanda. Same study was done by Khanna et al. (2000) in river Ganga at Rishikesh.The temperature showed an inverse relationship with the dissolved oxygen almost throughout the study as also reported by Das Khanna et al. (1993). The dissolved oxygen in water is often attributed to the fact that the oxygen is dissolved more during the period of photosynthesis, if the temperature is not too high. Temperature for aquatic life should be at least 200 $\mathrm{C}$ for survival. More beyond or less temperature may affect the aquatic life and other characteristics of water quality. During monsoon season water was turbid, $\mathrm{pH}$ fluctuated between 7.5 to 7.9. The minimum $\mathrm{pH}$ was recorded in monsoon 2010-2011 which was mainly attributed to rain water after a long dry period, and maximum $\mathrm{pH}$ was recorded during summer 2011-2012. Higher values of $\mathrm{pH}$ may be due to increased bathing / washing activities. Das (1961) reported that $\mathrm{pH}$ of water has an important behavior on both plankton and microbial production. He observed that a $\mathrm{pH}$ of 7.2 to 8.5 only was favorable for the growth of plankton and the higher values were detrimental to plankton production and thereby to the fish production also. Similar trend of $\mathrm{pH}$ were also found by Khanna et al (2001) in river Ganga has also observed the alkaline nature of water of river at Hardwar. 
Table 1. Physico-chemical parameters of River Bhagirathi during 2010-2012

\begin{tabular}{|l|l|l|l|l|l|l|l|}
\hline \multicolumn{1}{|c|}{ Parameters } & \multicolumn{3}{|c|}{ 2010-2011 } & \multicolumn{3}{|c|}{$\mathbf{2 0 1 1 - 2 0 1 2}$} & \\
\hline & Winter & Summer & Monsoon & Winter & Summer & Monsoon & Average \\
\hline Water Temp. $\left({ }^{\circ} \mathrm{C}\right)$ & 10.62 & 16.82 & 17.62 & 11.52 & 17.58 & 17.52 & $\mathbf{1 5 . 2 8}$ \\
\hline Velocity $(\mathrm{m} / \mathrm{s})(\mathrm{Fl}$ & 0.97 & 1.30 & 1.35 & 1.12 & 1.26 & 1.40 & $\mathbf{1 . 2 3}$ \\
\hline Turbidity $(\mathrm{JTU})$ & 25.10 & 30.95 & 407.87 & 22.52 & 30.38 & 409.45 & $\mathbf{1 5 4 . 3 8}$ \\
\hline $\begin{array}{l}\text { Conductivity } \\
\left(\mu \mathrm{mh} / \mathrm{cm}^{2}\right)\end{array}$ & 110.11 & 137.57 & 321.85 & 109.70 & 136.38 & 319.72 & $\mathbf{1 8 9 . 2 2}$ \\
\hline Total Solids $(\mathrm{mg} / \mathrm{l})$ & 266.91 & 594.10 & 1666.43 & 267.05 & 596.64 & 1672.87 & $\mathbf{8 4 4 . 0 0}$ \\
\hline TDS $(\mathrm{mg} / \mathrm{l})$ & 183.93 & 209.83 & 471.30 & 187.90 & 210.60 & 476.75 & $\mathbf{2 9 0 . 0 5}$ \\
\hline TSS $(\mathrm{mg} / \mathrm{l})$ & 82.98 & 384.26 & 1195.12 & 79.15 & 386.03 & 1196.12 & $\mathbf{5 5 3 . 9 4}$ \\
\hline pH & 7.93 & 7.70 & 7.59 & 7.77 & 7.63 & 7.55 & $\mathbf{7 . 7 0}$ \\
\hline DO $(\mathrm{mg} / \mathrm{l})$ & 9.75 & 7.77 & 8.08 & 9.67 & 8.03 & 7.94 & $\mathbf{8 . 5 4}$ \\
\hline Free $\mathrm{CO}(\mathrm{mg} / \mathrm{l})$ & 1.56 & 2.70 & 3.11 & 1.40 & 2.59 & 3.06 & $\mathbf{2 . 4 0}$ \\
\hline B.O.D. $(\mathrm{mg} / \mathrm{l})$ & 1.93 & 2.35 & 3.64 & 1.80 & 2.30 & 2.51 & $\mathbf{2 . 4 2}$ \\
\hline C.O.D. $(\mathrm{mg} / \mathrm{l})$ & 6.05 & 5.67 & 6.02 & 6.75 & 5.61 & 5.60 & $\mathbf{5 . 9 5}$ \\
\hline $\begin{array}{l}\text { Total Phosphate } \\
\text { (mg/l) }\end{array}$ & 0.08 & 0.02 & 0.10 & 0.08 & 0.02 & 0.10 & $\mathbf{0 . 0 7}$ \\
\hline $\begin{array}{l}\text { Total Hardness } \\
\text { (mg/l) }\end{array}$ & 95.99 & 85.35 & 109.43 & 96.30 & 84.95 & 108.38 & $\mathbf{9 6 . 7 3}$ \\
\hline Alkalinity $(\mathrm{mg} / \mathrm{l})$ & 67.02 & 78.51 & 54.25 & 68.65 & 79.45 & 54.80 & $\mathbf{6 7 . 1 1}$ \\
\hline Chloride $(\mathrm{mg} / \mathrm{l})$ & 1.85 & 2.70 & 10.75 & 1.80 & 2.62 & 10.56 & $\mathbf{5 . 0 4}$ \\
\hline Nitrate $(\mathrm{mg} / \mathrm{l})$ & 0.03 & 0.01 & 0.05 & 0.03 & 0.02 & 0.12 & $\mathbf{0 . 0 4}$ \\
\hline Sulphate $(\mathrm{mg} / \mathrm{l})$ & 19.50 & 11510.98 & 24.07 & 19.36 & 11457.49 & 24.07 & $\mathbf{3 8 4 2 . 5 8}$ \\
\hline
\end{tabular}

According to the study, river bhagirathi was measure of weak acid present in it and of the characterized by highest levels of dissolved oxygen cations against them (Sverdrup et al., 1942). with average value of $8.54 \mathrm{mg} / \mathrm{l}$. The highest oxygen Khanna (1993 and 2003) reported $75.3 \mathrm{mg} / 1$ to value of $9.7 \mathrm{mg} / \mathrm{l}$ was observed in winter season of $80.4 \mathrm{mg} / 1$ in river Ganga at Hardwar. Similar 2010-2011, dissolved oxygen showed a negative trends were reported by Chugh (2000), The factors trend with water temperature. The dissolved oxygen responsible for alkalinity included mixing of ashes, and free carbon-dioxide usually inversely related to waste water from different ashrams and washing one another because of the photosynthetic and activities. The average value of total hardness respiratory activities of the biota (Hynes, 1970) and during the study was $96.73 \mathrm{mg} / \mathrm{l}$ with lowest value lowest value of $7.7 \mathrm{mg} / \mathrm{l}$ was observed in summer of $84.95 \mathrm{mg} / \mathrm{l}$ during summer 2011-2012 and 2010-20111. Dissolved oxygen shows a significant highest value of $109.43 \mathrm{mg} / \mathrm{l}$ during monsoon 2010negative relation with temperature, alkalinity, total 2011.Khanna et al., (1993, 2003) and Mishra et al. hardness, velocity, nitrate, phosphate, chloride and (2003) observed hardness from $62.77 \mathrm{mg} / 1$ to respiration. The observed high value of dissolved $67.60 \mathrm{mg} / 1$ in river Ganga at Hardwar. Velocity oxygen in winter due to the high solubility at low was high during monsoon season, whereas winter temperature and less degradation of organic matter. season didn't show much variation. The monsoon So, within the study area we can say that from the season of 2010-2011 showed highest value of 1.40 point of view of dissolved oxygen the water quality $\mathrm{ms} / \mathrm{cm}$ and lowest value of $0.975 \mathrm{~ms} / \mathrm{cm}$ was of river Ganga can be good for drinking and observed in winter 2010-2011. In the present study, bathing purposes. Pahwa and Mehrotra (1966), Total Dissolved Solid (TDS) ranged have discussed the seasonal fluctuation of dissolved between $266 \mathrm{mg} / \mathrm{l}$ to $1672 \mathrm{mg} / \mathrm{l}$ with lowest during oxygen. During the study, the highest value of total winter 2010-2011 and highest during monsoon alkalinity was in summer 2011-2012 (79.45mg/l) 2011-12 respectively. Total solids were observed and lowest value was observed in monsoon 2010- maximum in the monsoon season that may be due $11(54.25 \mathrm{mg} / \mathrm{l})$. Total alkalinity shows a positive to high velocity of river water and waste water relationship with temperature, $\mathrm{pH}$, total hardness, runoff from sewage drains and agricultural lands. TDS, and conductivityTotal alkalinity of water is a The higher values of total solids are responsible for

\section{9}


the turbidity in the river. Similar trends were shown by Chugh (2000) in his thesis during the study of water quality of river Ganga at Hardwar and also by Khanna (1993). Total solids were recorded minimum in the winter season that may be due to gradual sedimentation of the settleable particles at the bottom of the river and also due to the lower velocity of the river which favours effective sedimentation. Chloride concentration varied between $1.8 \mathrm{mg} / \mathrm{l}$ noted during winter $2011-2012$ to $10.75 \mathrm{mg} / \mathrm{l}$ during monsoon 2010-2011. Mishra et al. (2003) recorded chloride values from $2.84 \mathrm{mg} / 1$ to $28.4 \mathrm{mg} / 1$ in river Ganga at Hardwar. According to the study, rich contents of nitrates were observed, with maximum of $0.59 \mathrm{mg} / 1$ during monsoon $2010-2011$ and minimum of $0.14 \mathrm{mg} / \mathrm{l}$ during summer 2010-2011. Nitrate concentration depends on the activity of nitrifying bacteria. High concentrations of nitrates were recorded after onset of rains ( Venkateswarlu, 1969). The minimum values of nitrates were recorded during summer season in the while maximum values of nitrate were recorded during monsoon season.
Fishes were collected from various spot of river Bhagirathi all through of the sampling range. From Bhatwari to Gangori besides S. richardsonii, the river also had two catfishes namely $G$. pectinopterus and $P$. sulcatus adapted to fast Flowing current of river. Another species of snowtrout, namely S. plagiostomus, was found at Bhatwari downstream. The two more species of snowtrots found in the Gangori (BhagirathiAsiganga confluence) were $\mathrm{S}$. curviforms and $\mathrm{S}$. progastus; they were also recorded from Bhatwari downwards. The famous Mahseer, Tor putitora, an endangered species of the Bhagirathi, was recorded from Gangori downwards. The Brown trout, Salmo truta fario, an introduced sp. In the Asiganga is thriving well since the habitat of stream is quite suitable for this species. From Asigaganga, some individuals of the brown trout also move into the river Bhagirathi and rare recorded there. 8 Species of fishes collected from River Bhagirathi. A systematic list of fish found during the course of study is given in table 2 and Fig. 1.

Table 2. List of Fishes found in River Bhagirathi during 2010-2012

\begin{tabular}{|c|c|c|c|c|c|}
\hline \multirow[t]{2}{*}{ S.N. } & \multirow{2}{*}{$\begin{array}{l}\text { Sampling } \\
\text { Stations }\end{array}$} & \multirow[t]{2}{*}{ Fish Species } & & \multicolumn{2}{|l|}{ Status } \\
\hline & & & & $2010-11$ & $2011-12$ \\
\hline 1. & Harsil & Schizothrox richardsonii (Gray) & Common & + & + \\
\hline 2. & Bhatwari & $\begin{array}{l}\text { Schizothrox richardsonii (Gray) } \\
\text { Glyptothorax pectinopterus } \text { (McClelland) } \\
\text { Schizothrox plagiostomus } \text { (Heckel) } \\
\text { Pseudecheneis sulcatus } \text { (McClelland) }\end{array}$ & $\begin{array}{l}\text { Common } \\
\text { Rare } \\
\text { Rare } \\
\text { Rare }\end{array}$ & $\begin{array}{l}+ \\
+ \\
- \\
+\end{array}$ & $\begin{array}{l}+ \\
- \\
+ \\
-\end{array}$ \\
\hline 3. & Gangori & $\begin{array}{l}\text { Schizothrox richardsonii (Gray) } \\
\text { Schizothraichthys curvifrons (Heckle) } \\
\text { Schizothrox plagiostomus (Heckel) } \\
\text { Schizothraichthys progastus (McClelland) } \\
\text { Tor putitora (Hamilton) } \\
\text { Salmo trutta fario (Linnaeus) } \\
\text { Pseudecheneis sulcatus } \text { (McClelland) } \\
\text { Glyptothorax pectinopterus (McClelland) }\end{array}$ & $\begin{array}{l}\text { Common } \\
\text { Rare } \\
\text { Rare } \\
\text { Rare } \\
\text { Rare } \\
\text { Common } \\
\text { Rare } \\
\text { Rare } \\
\end{array}$ & $\begin{array}{l}+ \\
- \\
- \\
+ \\
+ \\
+ \\
+ \\
+\end{array}$ & $\begin{array}{l}+ \\
+ \\
+ \\
- \\
- \\
+ \\
+\end{array}$ \\
\hline 4. & Uttarkashi & $\begin{array}{l}\text { Schizothrox richardsonii (Gray) } \\
\text { Schizothraichthys curvifrons (Heckle) } \\
\text { Schizothrox plagiostomus (Heckel) } \\
\text { Schizothraichthys progastus (McClelland) } \\
\text { Tor putitora (Hamilton) } \\
\text { Salmo trutta fario (Linnaeus) }\end{array}$ & $\begin{array}{l}\text { Common } \\
\text { Rare } \\
\text { Rare } \\
\text { Rare } \\
\text { Rare } \\
\text { Rare }\end{array}$ & $\begin{array}{l}+ \\
+ \\
+ \\
+ \\
-\end{array}$ & $\begin{array}{l}+ \\
- \\
- \\
+\end{array}$ \\
\hline
\end{tabular}


Earlier reports on the fish fauna of the Bhagirathi recorded seventeen indigenous and one exotic species (Badola and Pant, 1973). However, the present study recorded the presence of eight species only. The study further specified that Schizothorax richardsonii was present throught the stretch and contributed about $80-90 \%$ of the total catch. It may be mentioned that Bhatwari upwards, this was the only species present in the river. It may be further stated that the river had no fish species beyond Harsil (Baola and Pant, 1973).

\section{Conclusion}

In any aquatic ecosystem Limnological characteristic can affect both fauna and flora. Biodiversity contribute both directly and indirectly to human such as food for good health, security, social relationship, life and freedom for choice etc. In last decade people interfere with ecosystem and over exploitation of natural resources its result that biodiversity decreases. But the losses in biodiversity and change in ecosystem service have adversely affected the well-being. The present study is relevant to limnological study and fishe fauna of in River Bhagirathi. This study explains that River bhagirathi are in rich biodiversity fishes and need to conservation in future.

\section{References}

APHA, 1998. Standard Methods for the Examination of Water and Waste Water. 20th Edition. Washington: American Public Health Association.

Badola, S.P. and Singh, H.R. 1981. Hydrobiology of the river Alaknanda of Garhwal Himalaya Indian J. Ecol., 8(2):269-276.

Badola, S.P. 1979. Ecological studies on the Inchythofauna of some fresh water resources of Garhwal Region. D.Phil, Thesis, Garhwal University.

Das, S.M. 1961. Hydrogen ion concentration, plankton and fish in fresh water Eutrophic lakes of India, Nature 191 (4787): 511-12.

Hynes, H.B.N. 1970. The ecology of running waters. Liverpool University Press, Liverpool, 4th impression: 1555.

Jayaram, K.C. 1999. The freshwater fishes of the Indian Region. Narendra Publishing House, Delhi, 551.

Jhingran, V.G., Natarajan, A.G., Banerjee, S.M.and David, A. 1989. Methodology on the reservoir fisheries investigation in India. Barrack Pore: Bull. Cent. Inland. Fish. Inst., 12:102.

John, V. 1976. Hydrobiological studies on the river Kallayi in Kerala. Indian J. Fish., 23:72-85.
Khanna, D.R.and Singh, R.K. 2000. Seasonal fluctuation in plankton of Suswa river at Raiwala (Dehradun). Env. Cons. J. 1(2-3): 89-92.

Badola, S.P. and Pant, M.C., 1973. Fish fauna of Garhwal hills Part I., Ind J. Zool 14(1):37-44.

Khanna, D.R., Malik, D.S. and Badola, S.P. 1997. Population of green algae in relation to physico-chemical factors of the river Ganga at Lal-Ji-Wala, Hardwar. Uttar Pradesh J. Zool.17(3): 237-240.

Khanna, D.R., Malik, D.S. and Rana, D.S. 1997. Phytoplanktonic communities in relation to certain physico-chemical parameters of Ganga canal at Hardwar. Him. J. Env. Zool. 12:193-197.

Khanna, D.R.and Bhutiani, R. 2004. Water analysis at a glance, ASEA Publications. 1-115.

Khanna, D.R. and Chugh, T. 2004. Microbial ecology: A study of river Ganga, Discovery publishing House, New Delhi, 1-277.

Khanna, D.R., Pathak, S.K., Bhutiani, R. and Chandra, K.S. 2006. Study of water quality of river Suswa near Raiwala, Uttaranchal. Env. Cons. J. 7(3): 79-84.

Khanna, D.R., Gautam, Ashutosh, Chaugh, Tarun and Sarkar, Praveen 2000. Impact of abiotic factors on the phytoplanktonic population of a pond. Env. Con. J., 1 (1): $41-46$

Khanna, D.R., Chugh, Tarun and Sarkar, Praveen 2001. Fluctuations in the population density of Macro invertebrates of river Ganga at Pashulok Barrage Rishikesh (Uttaranchal, India). Env. Cons. J.,2(1): 3739.

Khanna, D.R. and Bhutiani, R. 2003. Limnological Characterstic of the Ganga at Haridwar (Uttarachal), U.P.J.Zool., Vol. 23(3): 179-183.

Misra, Sarika and Joshi B.D. 2003. Assessment of Water Quality with few selected parameter of River Ganga at Haridwar. Him.J. Env. Zool. Vol. 17 (2): 113-122.

Sverdrup, H.H., Johnson, M.W. and Fleming, R.H. 1942. The Oceans, their physics, chemistry and general biology. Prentice Hall, Inc., New York.

Trivedi, R.K. and Goel, P.K. 1986. Chemical and Biological method for water pollution studies. Karad Environmental Publications 1-251.

Venkateswarlu, T. 1969. An ecological study of the algae of the river Moosi Hyderabad (India) with special reference to water pollution I. Physico-chemical complexes. Hydrobiologia, 22(1): 117-143.

Wetzel, R.G.and Likens, G.E. 1991. Limnological analyses. Springer, New York, 1-175. 